\title{
Molecular and Serological Prevalence of Leptospira spp. in Feral Pigs (Sus scrofa) and their Habitats in Alabama, USA
}

\author{
Anil Poudel ${ }^{1}$, Md Monirul Hoque ${ }^{1}$, Steven Madere ${ }^{2}$, Sara Bolds ${ }^{2}{ }^{\circledR}$, Stuart Price ${ }^{1}$, \\ Subarna Barua ${ }^{1}$, Folasade Adekanmbi ${ }^{1}$, Anwar Kalalah ${ }^{1}$, Steven Kitchens ${ }^{1}$, Vienna Brown ${ }^{3}$, \\ Chengming Wang $1, * \mathbb{1}$ and B. Graeme Lockaby ${ }^{2, *}$ \\ 1 College of Veterinary Medicine, Auburn University, Auburn, AL 36849, USA; azp0012@auburn.edu (A.P.); \\ mzh0130@auburn.edu (M.M.H.); pricesb@auburn.edu (S.P.); szb0116@auburn.edu (S.B.); \\ fsa0004@auburn.edu (F.A.); aak0016@tigermail.auburn.edu (A.K.); srk0002@auburn.edu (S.K.) \\ 2 School of Forestry and Wildlife Sciences, Auburn University, Auburn, AL 36830, USA; \\ ssm0042@auburn.edu (S.M.); szb0132@auburn.edu (S.B.) \\ 3 USDA/APHIS/Wildlife Services, National Feral Swine Damage Management Program, \\ Fort Collins, CO 80521, USA; vienna.r.brown@usda.gov \\ * Correspondence: wangche@auburn.edu (C.W.); lockabg@auburn.edu (B.G.L.)
}

Received: 31 August 2020; Accepted: 19 October 2020; Published: 20 October 2020

\begin{abstract}
Leptospirosis is a widespread zoonosis and has been recognized as a re-emerging infectious disease in humans and a variety of wild and domestic animal species. In order to understand the prevalence and diversity of Leptospira spp. in feral pig populations of Alabama, we trapped 315 feral pigs in Bullock County east-central Alabama, and collected 97 environmental samples from riparian areas in Bullock County and Macon County east-central Alabama. Two previously published PCRs followed by DNA sequencing and BLASTn were performed to identify pathogenic Leptospira species in the kidney of feral pigs $(3.2 \%, 10 / 315)$ as well as environmental samples collected from the habitats of feral pigs $(2.1 \%, 2 / 97)$, but not in the whole blood samples $(\mathrm{n}=276)$ or spleen $(\mathrm{n}=51)$. An ELISA determined that $44.2 \%$ of serum samples $(122 / 276)$ were antibody-positive for Leptospira. The identification of two pathogenic Leptospira species from environmental samples and the high sero-positivity in feral pigs suggests potential pathogen shedding from feral pigs to environments, and to humans and domestic animals. In order to better understand the risk to human health associated with feral swine presence, further studies are warranted to explore the interrelationship between Leptospira spp. shedding in the urine of feral pigs and bacterial culture to explore pathogenicity. Multi-locus sequencing typing (MLST) and microscopic agglutination tests (MAT) should be performed in future studies to make a definite determination of pathogenic Leptospira in feral pigs in Alabama.
\end{abstract}

Keywords: pathogenic Leptospira; feral pigs; PCR; ELISA; USA

\section{Introduction}

Leptospirosis is a bacterial disease of global importance that affects humans and a variety of wild and domestic animal species. It causes major economic losses in farm animals and causes significant illness and mortality in humans as well. Worldwide, approximately 500,000 human cases are reported each year with a mortality rate between $5-20 \%$ [1]. This disease is zoonotic and may be transmitted to humans along several pathways, including direct contact with water contaminated by urine from infected animals. In addition, water recreationists and campers can become infected as a result of contact with contaminated streams, rivers, and lakes [2-5]. 
However, there have been few rigorous studies that examined the environmental phase of Leptospira [2]. Leptospirosis is primarily associated with rural areas although human outbreaks have occurred in urban environments as well. In rural environments, livestock and various wildlife species (raccoons, small mammals, and bats) may serve as a reservoir while rats and dogs are the most common hosts in urban environments [4]. Leptospira have been classified genetically into eight pathogenic genomospecies and serologically into more than 250 serovars. Three pathogenic species known to infect swine are Leptospira interrogans (serovars pomona, icterohaemorrhagiae, canicola, and bratislava), L. borgpetersenii (serovars sejroe and tarassovi) and L. kirschneri (serovar grippotyphosa). Serovars Pomona and Bratislava are uniquely adapted to swine while others are maintained in other species but sometimes infect swine [5]. L. interrogans serovar hardjo is the most important serovar of bovines and but also infects pig in close contact with cattle. L. interrogans serovar Bratislava is the most common strain in swine, though role of this serotype as a cause of disease is debated [6]. Pathogenic Leptospira produce biofilm, which helps their survival in the environment, such as in soil and water distribution systems. Bacterial aggregates morphologically similar to biofilms have been identified within the lumen of proximal renal tubules of reservoir hosts, potentially making them persistent and resistance to antibiotics $[7,8]$.

Feral pigs are considered to be the single most invasive animal species in the United States and have expanded from 17 to 38 states in the last 30 years [9]. The home range of feral swine has also spread to all 67 counties in Alabama [10]. Wild pigs have a very high rate of fecundity which poses great challenges with regard to efforts of preventing disease transmission through vaccination and the elimination of hosts as well as interventions related to the environmental conditions [3].

Although warnings of the leptospirosis risk associated with wild pigs have been issued for some parts of the United States, actual data regarding the magnitude of risk are scarce and primarily emanate from laboratory studies. Chatfeld et al. (2013) [11] found that 33\% of the 324 wild pigs sampled in Florida carried antibody to one or more serovars of Leptospira. Similarly, Buchholz et al. (2016) [12] estimated that $33.8 \%$ of 804 feral pigs sampled in Hawaii were antibody-positive to Leptospira serovars. This work suggests that such a high prevalence warranted a further investigation to better describe the role of wild pigs in the etiology of leptospirosis.

On a larger scale, Pedersen et al. (2015) [13] tested whole blood from 2055 wild pigs collected across the United States for antibody presence to six strains of Leptospira known to infect humans and domestic animals. They found that $13 \%$ of the samples tested positive for at least one strain, and concluded that Leptospira infection in wild pigs is common. However, Pedersen et al. (2017) [14] observed serovar antibodies in $53 \%$ of the 677 wild pigs sampled but noted that Leptospira DNA was found in only $3.4 \%$ of the associated kidneys. While this situation may imply a reduced risk, the authors emphasized the need for additional research in order to fully clarify the risk to human health posed by wild pigs.

While Leptospira serovars have been documented to be present in significant proportions of wild pig populations in the previously mentioned studies, there remains a critical lack of understanding of the nature of transmission risk to human health and the domestic swine population posed by Leptospira-infected feral swine. While Kaller et al. (2015) [15] recorded the presence of leptospires in surface waters within the Kistachie National Forest in western Louisiana, their data did not reveal spatial linkages between Leptospira and the presence of feral pigs.

Human risk of this disease is strongly linked to environmental conditions and is higher in the tropics due to elevated humidity and temperature. Risk and presence of Leptospira may also be associated with neutral to alkaline soils and water, temperatures from $4{ }^{\circ} \mathrm{C}$ to $40^{\circ} \mathrm{C}$, and soil moisture content above $20 \%$ [2]. It is currently assumed that pathogenic Leptospira can survive in the environment but do not multiply [16]. The bacterium can survive for about a week in moist soil and mud when temperature and other conditions are favorable [3], although Thibeaux et al. (2017) [16] found that pathogenic leptospires remained viable in soils for several weeks under laboratory conditions. 
Emerging evidence also supports the hypothesis that rainfalls re-suspend Leptospira with soil particles, which are carried to surface water, where animals and humans get exposed [17].

The main objectives of this study were to examine the prevalence of leptospirosis in feral swine populations in Alabama, and examine the presence of pathogenic Leptospira in stream water and stream bed sediments as the habitats of feral pigs, including a privately owned tract of land and a national forest.

\section{Results}

\subsection{Sample Compositions}

We collected whole blood and tissue specimens from a total of 315 feral swine at the privately owned land (POL), with paired whole blood and kidney specimens from 276 feral pigs. A total of 77 water samples were collected from the POL, and 20 were collected from Tuskegee National Forest (TNF) (Table 1).

Table 1. Leptospira-positive kidney tissue, environmental samples and the paired ELISA results.

\begin{tabular}{clllc}
\hline Specimen Type & Sample ID & \multicolumn{1}{c}{$\begin{array}{c}\text { Sampling } \\
\text { Dates }\end{array}$} & $\begin{array}{c}\text { Species Identified by } \\
\text { PCR }\end{array}$ & $\begin{array}{c}\text { Anti-Leptospira } \\
\text { IgG ELISA (OD Value) }\end{array}$ \\
\hline & EAPL-1-2 & July 19 & L. interrogans & 2.7 \\
& EAPL-5-7 & July 19 & L. interrogans & 1.36 \\
& EAPL-25-5 & August 19 & L. interrogans & 1.33 \\
Kidney & EAPL-30-18 & August 19 & L. noguchii & 1.57 \\
& EAPL-30-20 & August 19 & L. noguchii & 1.18 \\
& EAPL-50-4 & August 19 & L. noguchii & 2.15 \\
& EAPL-20-5 & September 19 & L. noguchii & 2.29 \\
& EAPL-36-12 & September 19 & L. noguchii & 3.22 \\
& EAPL-25-17 & November 19 & L. interrogans & 1.23 \\
Soil sediment & EAPL-5-4-9 & January 20 & L. noguchii & 1.21 \\
Stream water & Tusk-1W & July 2019 & L. noguchii & Not applicable \\
& Tuld 2019 & L. interrogans & Not applicable \\
\hline
\end{tabular}

\subsection{Molecular Detection of Leptospira Species}

PCR and DNA sequencing identified Leptospira DNA in 3.2\% of the kidney tissues (10/315), 2.1\% of environmental samples (2/97), but none of the 276 whole blood samples or 51 spleen samples. DNA sequencing of the qPCR products identified L. interrogans and L. noguchii in pigs at POL. L. interrogans was identified in one soil sediment sample from the TNF (1/20), and L. noguchii was found in one stream water sample from the POL (1/77).

The nucleotide sequences of L. interrogans identified in this study (GenBank Accession\#: MT447735) are identical to each other and show a full match to L. interrogans serovar Hardjo strain RTCC 2810 (KC800991) and serovar Gripotyphosa strain Moskva (EU871723). The nucleotide sequences of L. noguchii identified in this study (MT447736) are identical to each other and show a full match to that of L. noguchii strain LSU2580 (AY461919) and of the strain 1011 (AY461918).

\subsection{Detection of Anti-Leptospira IgG Antibody}

The uniformity of the optical density (OD) values was indicated by the control OD values that were within the acceptable range provided by the kit manufacturer and narrow $95 \%$ confident interval for substrate blank control $(0.091 \pm 0.001)$, negative control $(0.097 \pm 0.004)$, cut-off control $(1.042 \pm 0.023)$ and positive control $(2.713 \pm 0.075)$.

The porcine anti-Leptospira IgG antibody ELISA determined that $44.2 \%$ of serum samples $(122 / 276)$ were positive. The OD value detected in samples ranged from 1.1-6.8 fold higher than the cut-off OD with an average of 2.1-fold. Forty seven out of $276(17.0 \%)$ serum samples had an OD value at 
least twofold higher than the cut-off value, including $4.3 \%$ with an OD twofold higher. The highest percentage seropositive serum samples were from the month of July, followed by August and September. The monthly normalized OD ranged from a low of 1.4-fold in January 2020 to a high of 2.5-fold in September 2019.

Anti-Leptospira IgG antibodies were detected positive for the ten pigs that were also positive for Leptospira DNA by PCR (Table 2). Interestingly, the positivity of Leptospira IgG in feral pigs trapped in March 2020 was found to be significantly lower than those in July to September of 2019 (Table 2). Seasonal differences in the prevalence of Leptospira antibodies might be due to the change in the availability of plant foods and anthropogenic pressure in streams and lakes [18].

Table 2. Temporal distribution of anti-Leptospira IgG antibody-positive serum samples.

\begin{tabular}{lccl}
\hline Sampling Time & Total Assayed (N) & Positive (N) & \multicolumn{1}{c}{ Positivity (Confidence Interval) } \\
\hline July 2019 & 61 & 37 & $60.6 \%^{\mathrm{a}}(48.4 \%, 72.9 \%)$ \\
August 2019 & 35 & 20 & $57.1 \%^{\mathrm{a}}(40.8 \%, 73.5 \%)$ \\
September 2019 & 54 & 26 & $48.1 \%^{\mathrm{a}}(34.8 \%, 61.5 \%)$ \\
October 2019 & 46 & 16 & $34.8 \% \mathrm{ab}(21.0 \%, 48.6 \%)$ \\
November 2019 & 16 & 5 & $31.2 \% \mathrm{ab}(8.5 \%, 54.0 \%)$ \\
December 2019 & 14 & 5 & $35.7 \% \mathrm{ab}(10.6 \%, 60.8 \%)$ \\
January 2020 & 25 & 9 & $36.0 \mathrm{ab}(17.2 \%, 54.8 \%)$ \\
February 2020 & 7 & 2 & $28.6 \% \mathrm{ab}(8.2 \%, 64.1 \%)$ \\
March 2020 & 18 & 3 & $16.7 \% \mathrm{~b}(5.8 \%, 39.2 \%)$ \\
\hline
\end{tabular}

Numbers followed by different letters $(a, b)$ indicate significant differences between the positivity of Leptospira IgG antibody in different months of sampling times (Chi-squared test; $p<0.05$ ).

\section{Discussions}

In this study, we identified DNA of L. interrogans and L. noguchii, the two pathogenic species known to cause leptospirosis in human and animals, in kidneys from feral swine. We also identified both species from environmental samples suggesting the role of the environment in the spread of this pathogen. Strains of L. noguchii have been described infecting cattle [19-22] rats [23,24] and bats [25]. Apart from animal infections, the zoonotic aspect of this species has been suggested. A study in Nicaragua correlated L. noguchii infection in domestic animals with cumulative incidence of human cases [26], and severe clinical human cases were reported in Brazil [27]. Molecular epidemiology related to L. noguchii by Loureiro et al. [28] revealed important insights into the One Health context of this pathogen.

In contrast to a low number of detections of Leptospira DNA in feral pigs (blood: 0/276; spleen: 0/51; kidney: $10 / 345,3.2 \%$ ), we observed a $44.2 \%$ sero-positivity in these same animals. The discrepancy in PCR positivity and sero-positivity may be due to differences in the infectious state of the Leptospira spp. Leptospira infection typically either resolves or colonizes several target organs in the host, and disappears rapidly from circulation [29]. Chronic and asymptomatic Leptospira infections have been reported in several hosts [19-25]. The dissemination in blood usually precedes urinary shedding and colonization of kidney and spleen. Additionally, while PCR used in this study targets mainly the pathogenic Leptospira spp., the anti-Leptospira IgG ELISA detects antibodies against the infections of pathogenic and saprophytic Leptospira spp. This may partly explain the strong differences in the Leptospira positivity by PCR and ELISA.

Furthermore, the highly similar temporal distribution of normalized OD values in ELISA indicate that these pigs are constantly exposed to Leptospira species in the environment, and there is a real risk for cross-species transmission to wildlife species, livestock, and humans. Cross-species disease transmission between wildlife, domestic animals, and humans is an increasing threat to public and veterinary health $[30,31]$. Human leptospirosis occurs from indirect environment-mediated exposure to pathogenic leptospires through contaminated watered environments, possibly from the urine of infection animals, including feral pigs. The two pathogenic species of Leptospira detected in this study 
have been identified in several animal hosts in various parts of the world. Both of these Leptospira species were also detected in environmental samples (soil sediments and stream water), further corroborating the survival of leptospires in soil and sediments, and their role in transmission through surface water. Pathogenic Leptospira are known to produce biofilm that enables them to adapt to various environmental challenges $[7,10]$. The ability of pathogenic leptospires to survive in the aqueous environment is a key factor in transmission to new hosts [7]. L. noguchii was identified from sediment collected from the sites where pigs were trapped while L. interrogans was detected in stream water from our control site at TNF.

While leptospirosis is presumed to be the most widespread zoonoses worldwide, this disease at its onset is often misdiagnosed as a fever of unknown origin, aseptic meningitis, or influenza infection [32]. The microscopic agglutination test (MAT), showing a high sensitivity and allowing for the detection of serogroup specific antibodies [33], is the gold standard of the sero-diagnosis for leptospirosis. The IgG ELISA used in this study cannot differentiate the antibodies from infections between pathogenic and saprophytic Leptospira, or between different pathogenic Leptospira serovars. MAT should be used in the future studies to provide more definite sero-diagnosis of Leptospira in feral pigs in Alabama.

It is well-recognized that SYBR Greene PCR often confers false-positive results [34]. In this study, the highly specific (targeting pathogenic-Leptospira lig gene) and sensitive (a single copy of the target) FRET-PCR was performed to identify pathogenic Leptospira spp. [35]. Then, SYBR Greene PCR with a long amplicon [36] was run on those pathogenic Leptospira-positive samples, followed by DNA sequencing and BLASTn to identify the Leptospira species. The choice of using two PCRs was essential to identify pathogenic Leptospira spp., and minimize the workload in running PCR and performing DNA sequencing.

A Multilocus Sequence Typing (MLST) Scheme was successfully established to discriminate seven pathogenic Leptospira species [37]. Cilia et al. performed MLST to confirm the circulation of Tarassovi and Bratislava serogroups within wild boar in Tuscany [5]. The limitation of this study is that the determination of Leptospira species by PCR and DNA sequencing were not fully definite, and the MLST should be performed to make the definite determination of pathogenic serovars in the future study.

In conclusion, our PCR and serological data indicate that feral pigs present a risk of cross-species transmission of leptospirosis and may serve as a reservoir for this bacterium. The 3.2\% positivity based on PCR and $44.2 \%$ sero-positivity is very similar to a study conducted by Pedersen et al. in 129 counties of 29 states, including Alabama [13,14]. This and other studies underscored the difficulty in undertaking the true epidemiological investigation of Leptospira infection. Studies including the culture of the organism, MLST and diagnostic assays such as MAT would be required to fully understand the risk of cross-species transmission, especially to humans and domestic animals. A longitudinal study covering a wider area would be necessary to fully understand the influence of pig density in Leptospira infection cycle and the associated public health risk.

\section{Materials and Methods}

\subsection{Study Areas}

The experimental procedures in this study were approved by the Auburn University Institutional Animal Care and Use Committee (Approval number: 2017-3143).

This study was conducted at a privately owned tract of land in Bullock County (4515 hectares) [Figure 1] and the Tuskegee National Forest located in Macon County (4451 hectares) in east-central Alabama (latitude: 32.16857-32.70600 and longitude; 85.50155-85.57337). Both properties lie within the Upper Coastal Plain physiographic region and the Mantachie-Iuka-Bibb soil association. 


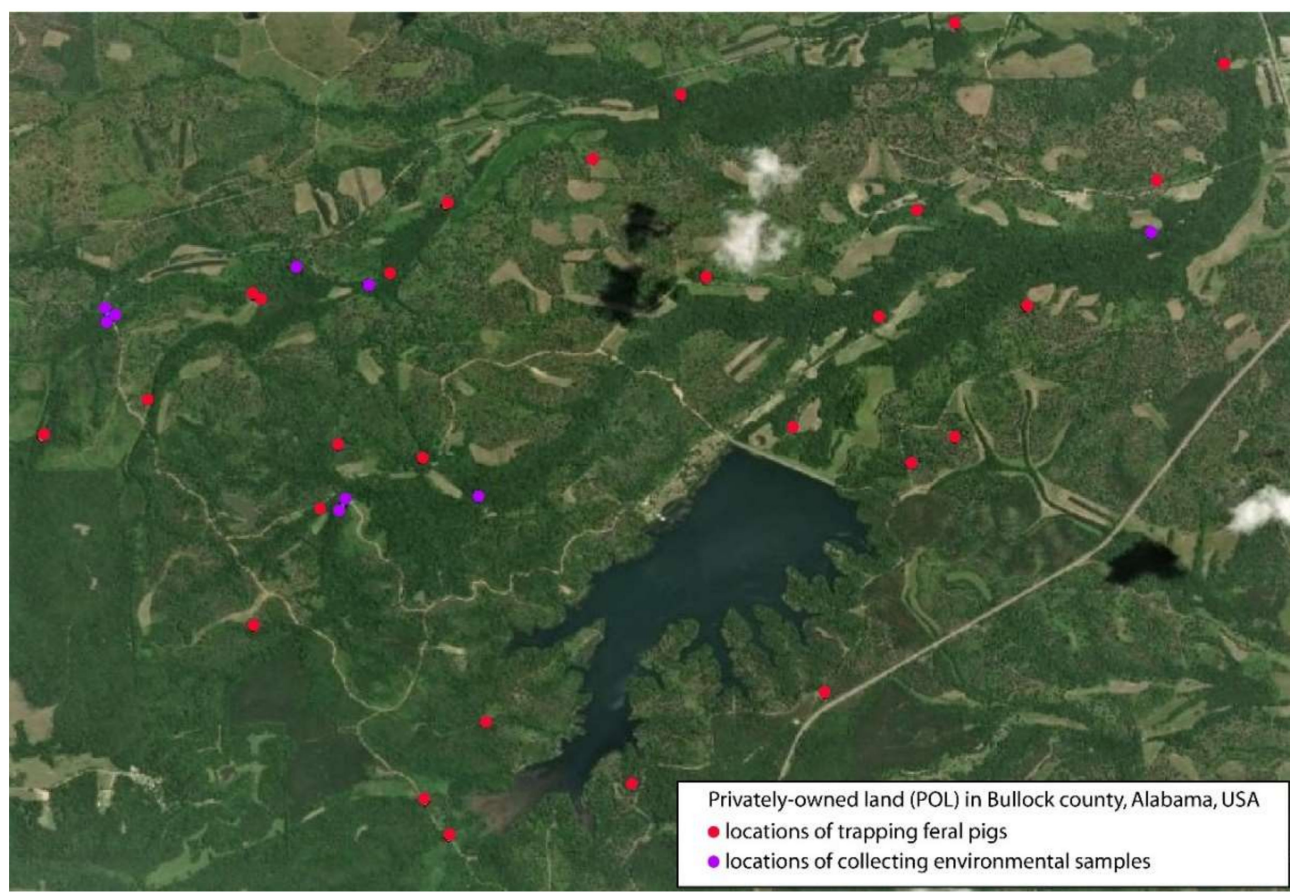

Figure 1. Locations at privately owned tract of land (POL) to trap feral pigs in this study. Feral pigs were trapped at a privately owned tract of land (POL) in Bullock County, 4515 hectares in east-central Alabama (latitude: 32.16857-32.70600 and longitude; 85.50155-85.57337). Feral pigs were trapped in 27 locations (red dots) while environmental samples were collected in 9 locations (purple dots). This figure was generated by the use of the software ArcMap 10.7.1(Redlands, CA, USA)

The POL was managed for white-tailed deer (Odocoileus virginianus) and eastern wild turkey (Meleagris gallopavo silvestris) populations, and was dominated by mixed pine (Pinus spp.) hardwood forest and riparian hardwoods. An earlier study at the private property estimated the wild pig density to be $15.5 \mathrm{pigs} / \mathrm{km}^{2}$, which is greater than the average density of $6-8 \mathrm{pigs} / \mathrm{km}^{2}$ in the region [38].

The study area at TNF was located approximately $25 \mathrm{~km}$ from the private property and was similar in terms of hydrology, watershed size, habitat type, and species composition. Wild pigs were present in the Tuskegee National Forest but were not yet established in the area selected for the study, which was confirmed with camera surveys.

Watersheds at both properties were surveyed to see if they met certain criteria: low gradient, occupied by deciduous wetland forests, and streams third order or lower streams that did not drain a standing body of water (e.g., a pond or lake). Eleven watersheds at the POL and three watersheds at the TNF were identified to be included in this study as they met the selection criteria. Floodplains at all watersheds were relatively flat with little to no riparian vegetarian buffer and soils were mainly composed of sandy bed loads. Stream flow was intermittent with peak flow occurring from November to April and greatly reduced flow during the summer months. Wild pig damage (rooting, digging, and wallowing) was observed at all selected watersheds on the POL, and occurred on the floodplains and within the stream channels throughout the year.

Water and stream sediment samples were collected at the 14 identified watersheds, while pigs were trapped at locations on the property that had frequent pig activity, which was determined by the amount of damage and number of pig sightings.

\subsection{Trapping of Feral Pigs and Collection of Tissues}

Between July 2019 and March 2020, 315 feral pigs were trapped in this study as part of a feral swine removal program funded by the USDA-APHIS. The pigs were captured using Jager Pro Hog Control Systems corral trap with a remotely activated gate. When pigs were seen on camera inside the 
trap, the gate would be activated via a cellular network to close. They were then euthanized by using a small caliber rifle.

Whole blood samples $(n=276)$ were collected into 5 mL EDTA tubes while kidney $(n=315)$ and spleen $(n=51)$ samples were stored in Ziploc bags. All samples were transported on ice to the research lab within three hours of sample collection.

Serum samples were separated by centrifuging the whole blood at $1000 \times g$ for $10 \mathrm{~min}$, and $200 \mu \mathrm{L}$ plasma were transferred to microcentrifuge tube and stored at $-20^{\circ} \mathrm{C}$. Remaining blood samples were mixed by vortex, transferred to microcentrifuge tubes and stored in $-20^{\circ} \mathrm{C}$ for nucleic acid extraction. A small portion of kidney and spleen tissues weighing approximately 200-300 mg was transferred to a microcentrifuge tube containing $-800 \mu \mathrm{L}$ of RNA/DNA stabilization buffer (Roche Diagnostics, Indianapolis, IN city, USA), and stored in $-20^{\circ} \mathrm{C}$ until nucleic acid extraction.

\subsection{Collection of Environmental Samples}

A total of 97 environmental samples (stream water and soil sediments) were collected during three sampling events, including 77 from the POL and 20 from the TNF. A drought during the summer of 2019 halted the collection of soil and water samples until stream flow increased at the sampling locations. Sampling at the properties occurred within $24 \mathrm{~h}$ of each other.

A wide-mouth collection bottle was rinsed in stream water before collection of a $500 \mathrm{~mL}$ grab sample. A soil auger was used to collect soil core samples to an approximate depth of $20 \mathrm{~cm}$, which were placed in Whirl-Pak bags. Two water samples and three soil samples were collected at each sampling site and combined into one water and one soil sample per watershed. All samples were kept on ice while in the field and at the laboratory.

Upon return to the laboratory, $50 \mathrm{~mL}$ of water from each composite sample was pipetted into $50 \mathrm{~mL}$ sterile plastic test tubes. For each composite soil sample, $5 \mathrm{~g}$ of soil and $40 \mathrm{~mL}$ of double-distilled water were added to a $50 \mathrm{~mL}$ sterile plastic test tube.

Samples were vortexed at maximum speed for $2 \mathrm{~min}$. Then, the environmental samples were centrifuged at $100 \times g$ for $5 \mathrm{~min}$. The supernatant $(30-35 \mathrm{~mL})$ was recovered and centrifuged at $12,000 \times g$ for $20 \mathrm{~min}$ at room temperature. The supernatant was discarded, pellet was recovered, re-suspended in $1.5 \mathrm{~mL}$ of sterile double distilled water and centrifuged at $12,000 \times \mathrm{g}$ for $20 \mathrm{~min}$. Finally, the supernatant was discarded and pellet were stored at $-20^{\circ} \mathrm{C}$ until nucleic acid extraction.

\subsection{Extraction of Nucleic Acids}

The High Pure PCR Template Kit (Roche Diagnostics, Indianapolis, IN, USA) was used to extract nucleic acids in this study from whole blood, kidney and spleen, and environmental samples as described [39].

Whole blood $(400 \mu \mathrm{L})$ was mixed with $400 \mu \mathrm{L}$ of binding buffer followed by homogenization. For kidney and spleen, 200-300 mg of samples were mixed with $800 \mu \mathrm{L}$ of RNA/DNA stabilization buffer and homogenized using 5 zirconia beads in a tissue homogenizer. For environmental samples, pellets were homogenized in $400 \mu \mathrm{L}$ of binding buffer using 5 zirconia beads. A homogenate aliquot of $100 \mu \mathrm{L}$ was mixed with $300 \mu \mathrm{L}$ of binding buffer. After digestion with proteinase $\mathrm{K}(10 \%$ of total volume), extraction was completed following the established laboratory protocol as described [39]. Nucleic acid was eluted in the final volume of $200 \mu \mathrm{L}$ using two step collection.

\subsection{Molecular Detection of Leptospira spp. and DNA Sequencing}

Two previously published PCRs $[35,36]$ were used to identify Leptospira spp. in pigs and environmental samples. PCR was performed on a Roche Light Cycler 480 II Thermocycler. The primers and probes for Leptospira FRET-qPCR and the primers for Leptospira SYBR Green PCR were synthesized by Integrated DNA Technologies (Coralville, IA, USA) as described [35,36]. Ten $\mu \mathrm{L}$ of the extracted DNA was added to a $10 \mu \mathrm{L}$ reaction mixture containing $5 \times$ PCR FRET buffer, $400 \mu \mathrm{M}$ dNTP (Roche Diagnostics GmbH, Indianapolis, IN, USA), 0.34 units of Platinum Taq DNA 
Polymerase (Invitrogen, Waltham, MA, USA), $1 \mu \mathrm{M}$ of each forward and reverse primer (Integrated DNA Technologies, Coralville, IA, USA) and a final volume of molecular grade nuclease-free water. PCR products for all positive and questionable samples were sent to ELIM Biopharmaceuticals (Hayward, CA, USA) for DNA sequencing using both ends of the primers, followed by BLASTn to identify the Leptospira species. The nucleotide sequences were submitted to NCBI to obtain GenBank Accession numbers.

\subsection{Anti-Leptospira spp. IgG ELISA}

The anti-Leptospira IgG antibody in pig plasma was measured by using the Porcine Leptospira IgG ELISA Kit (Novateinbio, Woburn, MA, USA) following the manufacturer's instructions. A positive control, cut-off control, negative control, and substrate blank were included on each plate, and an optical density (OD) was measured at $450 \mathrm{~nm}$ with reference wavelength of $620 \mathrm{~nm}$. Positive samples were interpreted as OD value higher than that of the cut-off OD value in each assay. The run validation and inter-assay precision was verified for its uniformity within range, using the similar OD values for controls, substrate blanks, and repeat testing of a select few samples.

\subsection{Statistical Analysis}

A chi-squared test was performed to compare the prevalence of anti-Leptospira IgG antibody-positive serum samples from pigs trapped in different months. Using bootstrapping, the $95 \%$ confidence intervals were calculated with the Statistics Base option in IBM SPSS Statistics for Windows, version 24.0 (IBM Corp., Armonk, NY, USA).

Author Contributions: B.G.L, C.W., A.P., S.P., S.B. (Sara Bolds), and V.B. designed the study, and wrote the proposal to obtain the funding. A.P., M.M.H., S.M., S.B. (Subarna Barua), S.B. (Sara Bolds), F.A., A.K. and S.K. collected the samples, performed the assays and analyzed the data. A.P., C.W., B.G.L., S.P., S.B. (Sara Bolds), V.B. and C.W. wrote the first draft of this manuscript which was read and approved by all authors. All authors have read and agreed to the published version of the manuscript.

Funding: This research was funded by the USDA APHIS (grant number: G00012580).

Conflicts of Interest: The authors declare no conflict of interest.

\section{References}

1. Dupouey, J.; Faucher, B.; Edouard, S.; Richet, H.; Kodjo, A.; Drancourt, M.; Davoust, B. Human leptospirosis: An emerging risk in Europe? Comp. Immunol. Microbiol. Infect. Dis. 2014, 37, 77-83. [CrossRef] [PubMed]

2. Barragan, V.; Olivas, S.; Keim, P.; Pearson, T. Critical knowledge gaps in our understanding of environmental cycling and transmission of Leptospira spp. Appl. Environ. Microbiol. 2017, 83, 1-10. [CrossRef] [PubMed]

3. Fentahun, T.; Alemayehu, M. Leptospirosis and its Public Health Significance: A Review. Eur. J. Appl. Sci. 2012, 4, 238-244. [CrossRef]

4. Bharti, A.R.; Nally, J.E.; Ricaldi, J.N.; Matthias, M.A.; Diaz, M.M.; Lovett, M.A.; Levett, P.N.; Gilman, R.H.; Willig, M.R.; Gotuzzo, E.; et al. Leptospirosis: A zoonotic disease of global importance. Lancet Infect. Dis. 2003, 3, 757-771. [CrossRef]

5. Cilia, G.; Bertelloni, F.; Angelini, M.; Cerri, D.; Fratini, F. Leptospira survey in Wild Boar (Sus scrofa) hunted in Tuscany, Central Italy. Pathogens 2020, 9, 377. [CrossRef]

6. Ngugi, J.N.; Fèvre, E.M.; Mgode, G.F.; Obonyo, M.; Mhamphi, G.G.; Otieno, C.A.; Cook, E.A.J. Seroprevalence and associated risk factors of leptospirosis in slaughter pigs; a neglected public health risk, western Kenya. BMC Vet. Res. 2019, 15, 403. [CrossRef]

7. Thibeaux, R.; Soupé-Gilbert, M.-E.; Kainiu, M.; Girault, D.; Bierque, E.; Fernandes, J.; Bähre, H.; Douyère, A.; Eskenazi, N.; Vinh, J.; et al. The zoonotic pathogen Leptospira interrogans mitigates environmental stress through cyclic-di-GMP-controlled biofilm production. NPJ Biofilms Microbiomes 2020, 6, 24. [CrossRef]

8. Wynwood, S.J.; Graham, G.C.; Weier, S.L.; Collet, T.A.; McKay, D.B.; Craig, S.B. Leptospirosis from water sources. Pathog. Glob. Health 2014, 108, 334-338. [CrossRef] 
9. Bevins, S.N.; Pedersen, K.; Lutman, M.W.; Gidlewski, T.; Deliberto, T.J. Consequences associated with the recent range expansion of nonnative feral swine. Bioscience 2014, 64, 291-299. [CrossRef]

10. Roney, M. Once Established, Feral Hogs Hard to Contain, Eradicate. AP News 2018. Available online: https://apnews.com/21973c7e025f4c48845178920e273e06 (accessed on 1 July 2020).

11. Chatfield, J.; Milleson, M.; Stoddard, R.; Bui, D.M.; Galloway, R. Serosurvey of leptospirosis in feral hogs (Sus scrofa) in Florida. J. Zoo Wildl. Med. 2013, 44, 404-407. [CrossRef] [PubMed]

12. Buchholz, A.E.; Katz, A.R.; Galloway, R.; Stoddard, R.A.; Goldstein, S.M. Feral Swine Leptospira Seroprevalence Survey in Hawaii, USA, 2007-2009. Zoonoses Public Health 2016, 63, 584-587. [CrossRef] [PubMed]

13. Pedersen, K.; Pabilonia, K.L.; Anderson, T.D.; Bevins, S.N.; Hicks, C.R.; Kloft, J.M.; Deliberto, T.J. Widespread detection of antibodies to Leptospira in feral swine in the United States. Epidemiol. Infect. 2015, 143, 2131-2136. [CrossRef] [PubMed]

14. Pedersen, K.; Anderson, T.D.; Bevins, S.N.; Pabilonia, K.L.; Whitley, P.N.; Virchow, D.R.; Gidlewski, T. Evidence of leptospirosis in the kidneys and serum of feral swine (Sus scrofa) in the United States. Epidemiol. Infect. 2017, 145, 87-94. [CrossRef] [PubMed]

15. Kaller, M.; Collier, B.; Achberger, E.; Barry, O. Detection of Feral Hog Impacts to Water Quality and Wildlife Final Report. 2000. Available online: https://www.wlf.louisiana.gov/assets/Resources/Publications/Feral_ Hogs/Detection_of_Feral_Hog_Impacts_to_Water_Quality_and_Wildlife_2016.pdf (accessed on 1 July 2020).

16. Thibeaux, R.; Geroult, S.; Benezech, C.; Chabaud, S.; Soupé-Gilbert, M.E.; Girault, D.; Bierque, E.; Goarant, C. Seeking the environmental source of Leptospirosis reveals durable bacterial viability in river soils. PLoS Negl. Trop. Dis. 2017, 11, 1-14. [CrossRef] [PubMed]

17. Bierque, E.; Thibeaux, R.; Girault, D.; Soupé-Gilbert, M.E.; Goarant, C. A systematic review of Leptospira in water and soil environments. PLoS ONE 2020, 15, e0227055. [CrossRef]

18. Aragón-Martínez, A.; Olivera-Gómez, L.D.; Jiménez-Domínguez, D. Seasonal prevalence of antibodies to Leptospira interrogans in Antillean manatees from a landlocked lake in Tabasco, Mexico. J. Wildl. Dis. 2014, 50, 505-511. [CrossRef]

19. Barragan, V.; Chiriboga, J.; Miller, E.; Olivas, S.; Birdsell, D.; Hepp, C.; Hornstra, H.; Schupp, J.M.; Morales, M.; Gonzalez, M.; et al. High Leptospira diversity in animals and humans complicates the search for common reservoirs of human disease in rural Ecuador. PLoS Negl. Trop. Dis. 2016, 10, e0004990. [CrossRef]

20. Hamond, C.; Pestana, C.P.; Medeiros, M.A.; Lilenbaum, W. Genotyping of Leptospira directly in urine samples of cattle demonstrates a diversity of species and strains in Brazil. Epidemiol. Infect. 2016, 144, 72-75. [CrossRef]

21. Martins, G.; Loureiro, A.P.; Hamond, C.; Pinna, M.H.; Bremont, S.; Bourhy, P.; Lilenbaum, W. First isolation of Leptospira noguchii serogroups Panama and Autumnalis from cattle. Epidemiol. Infect. 2015, 143, 1538-1541. [CrossRef]

22. Zarantonelli, L.; Suanes, A.; Meny, P.; Buroni, F.; Nieves, C.; Salaberry, X.; Briano, C.; Ashfield, N.; Da Silva Silveira, C.; Dutra, F.; et al. Isolation of pathogenic Leptospira strains from naturally infected cattle in Uruguay reveals high serovar diversity, and uncovers a relevant risk for human leptospirosis. PLoS Negl. Trop. Dis. 2008, 12, 1-22. [CrossRef]

23. Pellizzaro, M.; Conrado, F.D.O.; Martins, C.M.; Joaquim, S.F.; Ferreira, F.; Langoni, H.; Biondo, A.W. Serosurvey of Leptospira spp. and Toxoplasma gondii in rats captured from two zoos in Southern Brazil. Rev. Soc. Bras. Med. Trop. 2017, 50, 857-860. [CrossRef]

24. Vieira, A.S.; D’Andrea, P.S.; Vilela, R.d.V.; Loretto, D.; Jaeger, L.H.; Carvalho-Costa, F.A.; Lilenbaum, W. Pathogenic Leptospira species are widely disseminated among small mammals in Atlantic Forest biome. Transbound. Emerg. Dis. 2019, 66, 1195-1201. [CrossRef] [PubMed]

25. Ballados-González, G.G.; Sánchez-Montes, S.; Romero-Salas, D.; Colunga Salas, P.; Gutiérrez-Molina, R.; León-Paniagua, L.; Becker, I.; Méndez-Ojeda, M.L.; Barrientos-Salcedo, C.; Serna-Lagunes, R.; et al. Detection of pathogenic Leptospira species associated with phyllostomid bats (Mammalia: Chiroptera) from Veracruz, Mexico. Transbound. Emerg. Dis. 2018, 65, 773-781. [CrossRef] [PubMed]

26. Flores, B.J.; Pérez-Sánchez, T.; Fuertes, H.; Sheleby-Elías, J.; Múzquiz, J.L.; Jirón, W.; Duttmann, C.; Halaihel, N. A cross-sectional epidemiological study of domestic animals related to human leptospirosis cases in Nicaragua. Acta Trop. 2017, 170, 79-84. [CrossRef] [PubMed] 
27. Silva, É.F.; Cerqueira, G.M.; Seyffert, N.; Seixas, F.K.; Hartwig, D.D.; Athanazio, D.A.; Pinto, L.S.; Queiroz, A.; Ko, A.I.; Brod, C.S.; et al. Leptospira noguchii and human and animal Leptospirosis, Southern Brazil. Emerg. Infect. Dis. 2009, 15, 621-623. [CrossRef]

28. Loureiro, A.P.; Jaeger, L.H.; Di Azevedo, M.I.N.; Miraglia, F.; Moreno, L.Z.; Moreno, A.M.; Pestana, C.P.; Carvalho-Costa, F.A.; Medeiros, M.A.; Lilenbaum, W. Molecular epidemiology of Leptospira noguchii reveals important insights into a One Health context. Transbound. Emerg. Dis. 2020, 67, 276-283. [CrossRef] [PubMed]

29. Richer, L.; Potula, H.H.; Melo, R.; Vieira, A.; Gomes-Solecki, M. Mouse model for sublethal Leptospira interrogans infection. Infect. Immun. 2015, 83, 4693-4700. [CrossRef]

30. Dirsmith, K.; VanDalen, K.; Fry, T.; Charles, B.; VerCauteren, K.; Duncan, C. Leptospirosis in fox squirrels (Sciurus niger) of Larimer County, Colorado, USA. J. Wildl. Dis. 2013, 49, 641-645. [CrossRef]

31. Miller, R.S.; Sweeney, S.J.; Slootmaker, C.; Grear, D.A.; Di Salvo, P.A.; Kiser, D.; Shwiff, S.A. Cross-species transmission potential between wild pigs, livestock, poultry, wildlife, and humans: Implications for disease risk management in North America. Sci. Rep. 2017, 7, 1-14. [CrossRef]

32. Turner, L.H. Leptospirosis I. Trans. R. Soc. Trop. Med. Hyg. 1967, 61, 842-855. [CrossRef]

33. Budihal, S.V.; Perwez, K. Leptospirosis diagnosis: Competancy of various laboratory tests. J. Clin. Diagn. Res. 2014, 8, 199-202. [CrossRef] [PubMed]

34. Kaltenboeck, B.; Wang, C. Advances in real-time PCR: Application to clinical laboratory diagnostics. Adv. Clin. Chem. 2005, 40, 219-259. [CrossRef] [PubMed]

35. Xu, C.; Loftis, A.; Ahluwalia, S.K.; Gao, G.; Verma, A.; Wang, C.; Kaltenboeck, B. Diagnosis of canine leptospirosis by a highly sensitive FRET-PCR targeting the lig genes. PLoS ONE 2014, 9, e89507. [CrossRef] [PubMed]

36. Levett, P.N.; Morey, R.E.; Galloway, R.L.; Turner, D.E.; Steigerwalt, A.G.; Mayer, L.W. Detection of pathogenic Leptospires by real-time quantitative PCR. J. Med. Microbiol. 2005, 54, 45-49. [CrossRef] [PubMed]

37. Boonsilp, S.; Thaipadungpanit, J.; Amornchai, P.; Wuthiekanun, V.; Bailey, M.S.; Holden, M.T.; Zhang, C.; Jiang, X.; Koizumi, N.; Taylor, K.; et al. A single multilocus sequence typing (MLST) scheme for seven pathogenic Leptospira species. PLoS Negl. Trop. Dis. 2013, 7, e1954. [CrossRef]

38. Lewis, J.S.; Corn, J.L.; Mayer, J.J.; Jordan, T.R.; Farnsworth, M.L.; Burdett, C.L.; Ver Cauteren, K.C.; Sweeney, S.J.; Miller, R.S. Historical, current and potential population size estimates of invasive wild pigs (Sus scrofa) in the United States. Biol. Invasions 2019, 21, 2373-2384. [CrossRef]

39. Wei, L.; Kelly, P.; Zhang, J.; Yang, Y.; Zheng, X.; Tao, J.; Zhang, Z.; Wang, C. Use of a universal hydroxymethylbilane synthase (HMBS)-based PCR as an endogenous internal control and to enable typing of mammalian DNAs. Appl. Microbiol. Biotechnol. 2014, 98, 5579-5587. [CrossRef]

Publisher's Note: MDPI stays neutral with regard to jurisdictional claims in published maps and institutional affiliations.

(C) 2020 by the authors. Licensee MDPI, Basel, Switzerland. This article is an open access article distributed under the terms and conditions of the Creative Commons Attribution (CC BY) license (http://creativecommons.org/licenses/by/4.0/). 